\title{
STATUS GRAVIDA, PERTAMBAHAN BERAT BADAN, UKURAN LINGKAR LENGAN ATAS (LILA) DENGAN KEJADIAN PREEKLAMPSIA DI RSUD DOKTER SOEDARSO PONTIANAK
}

\author{
Gravida Status, Weight Gain, Upper Arm Circumference (LILA) With The Incidence Of \\ Preeclampsia in RSUD Dokter Soedarso Pontianak
}

\author{
Bitania Aminudin, Marlenywati, M.Taufik \\ Fakultas IImu Kesehatan Universitas Muhammadiyah Pontianak
}

E-mail korespondensi, bitaniamdf@gmail.com

\begin{abstract}
Preeclampsia is an increase in blood pressure of more than $140 / 90 \mathrm{mmHg}$, there is a urine protein content and experience swelling of the face, feet, hands and eyes. Factors that can cause cases of preeclampsia in pregnant women are gravid status, having experienced preeclampsia before, having certain diseases, more than one fetus, age factor, obesity during pregnancy, and heredity. At the Doctor Soedarso Regional General Hospital in Pontianak, the location of the study was obtained in 2017 with a total of 1509 deliveries with 224 cases of preeclampsia. This study aims to determine the relationship between gravida status, weight gain, upper arm circumference size (LILA) to the incidence of preeclampsia in pregnancy in the work area of the Regional General Hospital of Doctor Soedarso Pontianak. The study used a cross sectional design. The total sample of 51 pregnant women (35 severe preeclampsia and 16 mild preeclampsia) were taken by purposive sampling technique. The statistical test used chi-square test with a confidence level of 95\%. The results showed that there was a significant correlation between gravida status ( $p$ value $=0,000, P R=3,543,95 \% \mathrm{Cl}=1,504$ 8,347), weight gain ( $p$ value $=0,027, P R=1,627,95 \% \mathrm{Cl}=1,079-2,454)$, and there was no significant relationship between the size of the Upper Arm Circumference ( $L I L A)$ ( $p$ value $=0.253, P R=0.589,95 \% \mathrm{Cl}=0.246-1,413$ ) with the incidence of preeclampsia in pregnant women in Dokter Soedarso General Hospital Pontianak.
\end{abstract}

Keywords: Gravida status, weight gain, upper arm circumference size (LILA)

\section{ABSTRAK}

Preeklampsia adalah terjadinya peningkatan tekanan darah lebih dari $140 / 90 \mathrm{mmHg}$, terdapat kandungan protein urine dan mengalami pembengkakan pada muka, kaki, tangan, dan mata. Faktor yang dapat menyebabkan terjadinya kasus preeklampsia pada ibu hamil adalah status gravida, pernah mengalami preeklampsia sebelumnya, sedang mengidap beberapa penyakit tertentu, janin yang dikandung lebih dari satu, faktor usia, obesitas saat hamil, dan faktor keturunan. Di Rumah Sakit Umum Daerah Dokter Soedarso Pontianak yang menjadi lokasi penelitian diperoleh pada tahun 2017 total persalinan 1509 persalinan dengan kasus preeklampsia sebanyak 224 kasus. Penelitian ini bertujuan mengetahui hubungan antara status gravida, pertambahan berat badan, ukuran lingkar lengan atas (LILA) terhadap kejadian preeklampsia pada kehamilan di wilayah kerja Rumah Sakit Umum Daerah Dokter Soedarso Pontianak. Penelitian menggunakan desain cross sectional. Jumlah sampel sebanyak 51 ibu hamil (35 preeklampsia berat dan 16 preeklampsia ringan) yang diambil dengan teknik purposive sampling. Uji statistik yang digunakan uji chi-square dengan tingkat kepercayaan 95\%. Hasil penelitian menunjukkan terdapat hubungan yang bermakna antara status gravida ( $p$ value $=0,000, \mathrm{PR}=3,543, \mathrm{Cl} 95 \%=1,504-8,347)$, pertambahan berat badan $(p$ value $=0,027, \mathrm{PR}=1,627, \mathrm{Cl} 95 \%=1,079-$ 2,454 ), dan tidak terdapat hubungan bermakna antara ukuran Lingkar Lengan Atas (LILA) ( $p$ value $=0,253, P R=0,589, \mathrm{Cl}$ $95 \%=0,246-1,413$ ) dengan kejadian preeklampsia pada ibu hamil di RSUD Dokter Soedarso Pontianak.

Kata Kunci : Status Gravida, Pertambahan Berat Badan, Ukuran Lingkar Lengan Atas (LILA)

PENDAHULUAN

Angka Kematian Ibu (AKI) dan Angka Kematian Bayi (AKB) merupakan suatu indikator penting untuk menilai tingkat kesejahteraan pada suatu negara dan status kesehatan masyarakat. Angka Kematian Ibu (AKI) masih tinggi, hal ini menunjukkan sistem pelayanan obstetric di negara tersebut masih buruk sehingga memerlukan perbaikan. Penyebab angka kematian bayi sebagian besar berkaitan dengan status kesehatan ibu saat hamil, pengetahuan ibu dan keluarga terhadap pentingnya pemeriksaan kehamilan dan peranan tenaga kesehatan serta ketersediaan fasilitas kesehatan (Ambarwati, 2009).
Kematian dan kesakitan ibu masih merupakan masalah kesehatan yang serius di negara berkembang. Menurut laporan World Health Organization (WHO) tahun 2014 Angka Kematian Ibu (AKI) didunia yaitu 289.000 jiwa. Beberapa negara memiliki AKI cukup tinggi seperti Afrika SubSaharan 179.000 jiwa, Asia Selatan 69.000 jiwa, dan Asia Tenggara 16.000 jiwa. Angka kematian ibu di negara-negara Asia Tenggara yaitu Indonesia 190 per 100.000 kelahiran hidup, Vietnam 49 per 100.000 kelahiran hidup, Thailand 26 per 100.000 kelahiran hidup, Brunei 27 per 100.000 kelahiran hidup, dan Malaysia 29 per 100.000 kelahiran hidup (WHO, 2014). 
Survei Demografi Kesehatan Indonesia (SDKI) tahun 2009 menyatakan bahwa AKI di Indonesia 226 per 100.000 kelahiran hidup. Dan pada tahun 2010 meningkat menjadi 228 per 100.000 kelahiran hidup, pada tahun 2013 SDKI kembali mencatat kenaikan AKI yang signifikan yakni dari 228 menjadi 359 kematian ibu per 100.000 kelahiran hidup. Penyebab AKI di Indonesia adalah perdarahan $25 \%$, partus tak maju $17 \%$, infeksi $13 \%$, aborsi tidak aman 13\%, eklamsia $12 \%$, dan penyebab lain $12 \%$ (Kemenkes, 2014).

Preeklampsia adalah sebuah komplikasi pada kehamilan yang ditandai dengan tekanan darah tinggi dan tandatanda kerusakan organ seperti kerusakan ginjal yang ditunjukkan oleh tingginya kadar protein pada urine (proteinuria). Hal ini ditandai dengan meningkatnya tekanan darah lebih dari $140 / 90 \mathrm{mmHg}$ dan protein dalam urine ibu hamil, sesak nafas karena adanya cairan di paru-paru, sakit kepala hebat, gangguan penglihatan, mual dan muntah berlebih, berkurangnya volume urine, pembengkakan pada telapak kaki, pergelangan kaki, wajah dan tangan. Sindroma preeklampsia ringan seperti hipertensi, oedema, dan proteinuria sering tidak diperhatikan, sehingga tanpa disadari dalam waktu singkat dapat timbul preeklamsia berat, bahkan eklampsia (Prawirohardjo, 2010).

Ibu yang mengalami preeklampsia biasanya akan mengalami gejala dan tanda antara lain tiba-tiba mengalami pembengkakan pada muka, kaki, tangan, dan mata, tekanan darah menjadi sangat tinggi yaitu lebih dari 140/90 $\mathrm{mmHg}$, terjadi peningkatan berat badan dalam 1 atau 2 hari, nyeri pada perut bagian atas, nyeri kepala yang sangat parah, timbul rasa mual dan muntah, penglihatan kabur, penurunan frekuensi dan jumlah urin, terdapat protein pada urin hal ini diketahui setelah melakukan pemeriksaan urin (Firman, 2012).

Beberapa faktor yang dapat meningkatkan resiko seorang ibu hamil mengalami preeklampsia adalah kehamilan pertama, pernah mengalami preeklamsia pada kehamilan sebelumnya, sedang mengidap beberapa penyakit tertentu seperti diabetes, lupus atau penyakit ginjal, janin yang dikandung lebih dari satu, hamil setelah jeda 10 tahun dari kehamilan sebelumnya, faktor usia, obesitas saat hamil, dan faktor keturunan (Gafur, 2012).
Dampak dari kejadian preeklampsia dalam kehamilan adalah sindrom HELLP (Haemollysis-Elevated Liver Enzymes and Low Platelet Count) atau hemolisis, eklampsia, penyakit kardiovaskular, kegagalan organ lain, rusaknya sistem penggumpalan darah, erupsi plasenta, dan stroke hemoragik (Trijatmo, 2007).

Angka Kematian lbu di provinsi Kalimantan Barat dari tahun 2013 adalah 96 per 100.000 kelahiran hidup, tahun 2014 adalah 296 per 100.000 kelahiran hidup, dan pada tahun 2015 adalah 261 per 100.000 kelahiran hidup. Ditinjau dari penyebab kematiannya, $38,46 \%$ kematian ibu disebabkan oleh perdarahan, hipertensi dalam kehamilan sebesar $26,17 \%$, infeksi 4,20\%, dan lain-lain 32,17\% (Dinkes Kalbar, 2016).

Data yang diperoleh dari RSUD Dokter Soedarso dari bulan JanuariDesember 2016 terdapat 1472 total persalinan, dengan 249 kasus preeklampsia yang bahkan sampai kepada eklampsia dan menyebabkan kematian. Pada tahun 2017 total persalinan mencapai 1509 dengan kasus preeklampsia mengalami penurunan meskipun tidak terlalu banyak sebanyak 224. Data terakhir yang diperoleh dari bulan Januari sampai Juli 2018 sebanyak 162 kasus.

Hasil pengamatan dari medical record, di RSUD Dokter Soedarso Pontianak menunjukkan bahwa sebagian besar para ibu yang mengalami preeklampsia memiliki anak satu sebesar $32,2 \%$, yang memiliki anak lebih dari satu sebesar $59,4 \%$, dan yang memiliki anak lebih lima atau lebih dari lima sebesar 8,4\%.

Menurut Wantonoro (2015), berdasarkan ibu hamil yang berisiko dan tidak berisiko mengalami preeklampsia ternyata ibu hamil dengan paritas berisiko mengalami kejadian preeklampsia sehingga ada hubungan antara paritas dengan kejadian preklampsia. Hasil penelitian dari Anas (2013) menyatakan adanya hubungan antara lingkar lengan atas (LILA) dengan kejadian preeklampsia. Hasil penelitian lainnya, Situmorang (2016) menyatakan ada hubungan antara umur dan pengetahuan dengan kejadian preeklampsia pada ibu hamil dan tidak ada hubungan antara paritas, riwayat hipertensi, dan pemeriksaan ANC dengan kejadian preeklampsia pada ibu hamil.

Dari hasil-hasil penelitian yang telah dilakukan sebelumnya dan penyebab 
terjadinya kasus preeklampsia pada kehamilan, tujuan penelitian ini adalah ingin mengetahui apakah ada hubungan antara status gravida, pertambahan berat badan, ukuran lingkar lengan atas (LILA) dengan kejadian preeklampsia pada kehamilan di RSUD Dokter Soedarso.

\section{METODE}

\section{Desain,Waktu dan Tempat}

Penelitian yang digunakan adalah cross sectional dengan teknik purposive sampling. Penelitian ini dilaksanakan pada tanggal 25 Oktober 2018-28 November 2018. Dan bertempat di Rumah Sakit Umum Daerah Dokter Soedarso Pontianak.

\section{Jumlah dan Cara Pengambilan Subjek}

Populasi penelitian ini adalah seluruh ibu hamil yang dirawat dengan kasus preeklampsia sebanyak 59. Berdasarkan populasinya maka dapat diambil sampel rumus Lemeshow sebanyak 51 responden dari ibu hamil dengan preeklampsia.

\section{Jenis dan Cara Pengumpulan Data}

Pengumpulan data dilakukan menggunakan kuesioner yang terdiri dari data responden serta hasil pemeriksaan responden berdasarkan dari medical record dan buku Kesehatan Ibu dan Anak (KIA) yang dimiliki oleh responden. Data primer diperoleh berdasarkan hasil jawaban responden atas pertanyaan dan pernyataan yang diberikan.

\section{Pengolahan dan Analisis Data}

Pengolahan data dilakukan dengan analisa data berupa analisa univariat yaitu data yang diperoleh dari masing-masing variabel dimasukkan kedalam variabel frekuensi. Selanjutnya dilakukan analisa bivariat yaitu untuk mengetahui atau menguji hubungan antara variabel bebas dengan variabel terikat menggunakan uji chi square dengan derajat kepercayaan $95 \%$.

\section{Hasil}

Berdasarkan data karakteristik responden berdasarkan umur dimana umur terbanyak yaitu $>35$ tahun sebanyak 24 responden $(47,1 \%)$ dan umur terendah $<20$ tahun sebanyak 4 responden $(7,8 \%)$. Berdasarkan pendidikan terakhir responden yang terbanyak yaitu tamat SMA sebanyak 24 responden (47\%) dan paling sedikit responden yang tamat universitas sebanyak 2 responden (3,9\%). Berdasarkan pekerjaan responden yang paling banyak adalah tidak bekerja (IRT) sebanyak 37 responden $(72,6 \%)$ dan paling sedikit responden sebagai pegawai negri yaitu 1 responden $(1,9 \%)$. Berdasarkan tinggi badan responden yang memiliki tinggi badan $>145$ $\mathrm{cm}$ lebih banyak yaitu 46 responden $(90,2 \%)$ dan tinggi badan $<145 \mathrm{~cm}$ paling sedikit yaitu 5 responden $(9,8 \%)$.

Hasil analisis univariat responden yang mengalami preeklampsia berdasarkan status gravida, dimana status gravida terbanyak yaitu multigravida sebanyak 35 responden $(68,6 \%)$ dan status gravida paling sedikit yaitu primigravida sebanyak 16 responden $(31,4 \%)$. Berdasarkan pertambahan berat badan, responden dengan preeklampsia yang mengalami pertambahan berat berlebih lebih banyak yaitu 26 responden $(51 \%)$ dan responden yang mengalami pertambahan berat badan normal paling sedikit yaitu 25 responden (49\%). Berdasarkan Lingkar Lengan Atas (LILA, dimana responden yang tidak risiko KEK lebih banyak yaitu 44 responden $(86,3 \%)$ sedangkan responden dengan risiko KEK paling sedikit yaitu sebanyak 7 responden (13,7\%).

Hasil bivariat diperoleh hubungan antara status gravida dengan kejadian preeklampsia pada ibu hamil dengan uji $c h i$ square diperoleh $p=0,000$ jika dibandingkan dengan nilai $\alpha=0,005$ maka $p<\alpha$. hal tersebut menunjukkan bahwa terdapat hubungan status gravida dengan kejadian preeklampsia pada iu hamil di RSUD Dokter Soedarso Pontianak.

Diperoleh data hubungan pertambahan berat badan dengan kejadian preeklampsia pada ibu hamil dengan uji statistik chi square diperoleh nilai $p=0,027$ jika dibandingkan dengan nilai $\alpha=0,05$, maka $p<\alpha$. Hal tersebut menunjukkan bahwa terdapat hubungan antara pertambahan berat badan dengan kejadian preeklampsia pada ibu hamil di RSUD Dokter Soedarso Pontianak.

Didapatkan data hubungan Lingkar Lengan Atas (LILA) dengan kejadian preeklampsia pada ibu hamil dengan uji statistik chi square dengan nilai $p=0,253$ jika dibandingkan dengan nilai $\alpha=0,05$, maka $p>\alpha$. Ini menunjukkan bahwa tidak terdapat hubungan antara Lingkar Lengan Atas (LILA) dengan kejadian preeklampsia pada ibu hamil di RSUD Dokter Soedarso Pontianak. 


\section{PEMBAHASAN}

Dalam pembahasan ini akan diarahkan untuk mengetahui hubungan status gravida, pertambahan berat badan, ukuran Lingkar Lengan Atas (LILA) dengan kejadian preeklampsia pada ibu hamil di RSUD Dokter Soedarso Pontianak.

Hasil analisis antara variabel hubungan status gravida dengan kejadian preeklampsia pada ibu hamil di RSUD Dokter Soedarso Pontianak dengan uji statistik chi square diperoleh nilai $p=0,000$ jika dibandingkan nilai $\alpha=0,05$, maka $p<\alpha$. Hal tersebut menunjukkan bahwa terdapat hubungan status gravida dengan kejadian preeklampsia pada ibu hamil di RSUD Dokter Soedarso Pontianak.

Hal tersebut sejalan dengan penelitian Serudji, ditemukan adanya hubungan yang signifikan antara status gravida dengan kejadian preeklampsia. Ditemukan proporsi primigravida yang menderita preeklampsia 1,52 kali lebih banyak daripada primigravida yang tidak preeklampsia, sedangkan proporsi multigravida yang tidak menderita preeklampsia 1,3 kali lebih banyak daripada multigravida yang menderita preeklampsia. Maknanya, seorang primigravida mempunyai kecenderungan untuk mengalami preeklampsia dibandingkan dengan multigravida (Serudji, 2013)

Seperti penelitian Artikasari pada RSUD Dr. Moewardi Surakarta ditemukan 35 dari 60 primigravida menderita preeklampsia dan hanya 24 dari 60 multigravida yang menderita preeklampsia. Dari hasil uji chi square nilai $p=0,045$ yang berarti bahwa terdapat hubungan yang signifikan antara primigravida dengan kejadian preeklampsia dimana pada primigravida berisiko 1,458 kali lebih besar untuk menderita preeklampsia dibandingkan multigravida (Artikasari, 2009).

Secara teori, primigravida lebih berisiko untuk mengalami preeklampsia daripada multigravida. Karena preeklampsia biasanya timbul pada wanita yang pertama kali terpapar virus korion. Hal ini terjadi karena pada wanita tersebut mekanisme imunologik pembentukan blocking antibody yang dilakukan oleh HLA-G (human leukocyte antigen $\mathrm{G}$ ) terhadap antigen plasenta belum terbentuk secara sempurna, sehingga proses implantasi trofoblas ke jaringan desidual ibu menjadi terganggu. Primigravida juga rentan mengalami stres dalam menghadapi persalinan yang akan menstimulasi tubuh untuk mengeluarkan kortisol. Efek kortisol adalah meningkatkan respon simpatis, sehingga curah jantung dan tekanan darah juga akan meningkat (Eiland, 2012). Namun dari hasil penelitian ini dapat dilihat bahwa kasus preeklampsia lebih banyak terjadi pada multigravida dibandingkan primigravida, hal ini dikarenakan sampel dalam penelitian ini kebanyakan adalah ibu-ibu hamil dengan faktor risiko umur > 35 tahun, yang juga merupakan salah satu faktor penyebab terjadinya preeklampsia dalam kehamilan.

Hasil analisis hubungan pertambahan berat badan dengan kejadian preeklampsia berdasarkan uji chi square diperoleh nilai $p=0,027$ jika dibandingkan dengan nilai $\alpha=0,05$, maka $p<\alpha$. Hal tersebut menunjukkan bahwa terdapat hubungan antara pertambahan berat badan dengan kejadian preeklampsia pada ibu hamil di RSUD Dokter Soedarso Pontianak.

Penelitian Riestyawati dari hasil penghitungan statistik, menunjukkan bahwa ada pengaruh yang signifikan antara pertambahan berat badan dengan kejadiaan preeklampsia di Bangsal Kandungan RSUP Dr. Soeradji Tirtonegoro, RS. Islam dan RS. Khusus Ibu dan Anak "Aisyiyah" Kabupaten Klaten. Faktor predisposisi yang berhubungan dengan kejadian preeklampsia diantaranya adalah primigravida, obesitas, kenaikan berat badan yang berlebihan dan tingkat kecukupan gizi (protein, kalsium). Preeklampsia masih sulit ditanggulangi ataupun dicegah. Nutrisi yang baik memberikan kontrisbusi dalam menurunkan insiden dan mortalitas preklampsia.

Status berat badan sebelum hamil mempengaruhi hubungan antara kenaikan berat badan ibu selama hamil dan berat badan bayi saat lahir. Karena ibu hamil yang underweight cenderung mempertahankan kenaikan berat badannya selama hamil untuk kebutuhan dirinya sendiri, mereka perlu menaikkan berat badannya lebih dari ibu hamil lainnya selama kehamilan. Sedangkan ibu hamil yang mempunyai berat badan lebih bisa menggunakan sebagian dari cadangan energinya untuk mendukung pertumbuhan janin, sehingga mereka hanya perlu sedikit menaikkan berat badan. Kenaikan berat badan selama kehamilan tidak menjamin bayi akan mempunyai berat badan normal saat lahir karena banyak faktor lain yang mempengaruhi berat badan bayi lahir. Namun, menaikkan berat badan selama hamil dapat meningkatkan peluang 
berat badan bayi baru lahir berada di kisaran normal (Simkin, 2010).

Dari hasil penelitian ini dapat disimpulkan, pertambahan berat badan ibu hamil dari trimester 1 hingga trimester 3 juga merupakan salah satu faktor terjadinya preeklampsia dalam kehamilan. Dari analisis pertambahan berat badan ditemukan juga bahwa Indeks Masa Tubuh (IMT) sebelum hamil juga merupakan faktor penyebab terjadinya kasus preeklampsia. Dan rata-rata dari ibu yang memiliki IMT sebelum hamil normal mengalami kenaikan berat badan yang berlebih. Hal ini mungkin dapat juga dipengaruhi dari asupan makanan yang dikonsumsi ibu selama hamil. Dengan demikian ibu hamil dapat mendiskusikan asupan nutrisi seperti apa yang dapat dikonsumsi ibu hamil agar pertambahan berat badan tidak terlalu berlebih dengan ahli gizi dipusat pelayanan kesehatan. Sehingga ibu hamil sendiri dapat lebih mengontrol asupan makanan yang dikonsumsinya selama hamil.

Hasil analisis hubungan Lingkar Lengan Atas (LILA) dengan kejadian preeklampsia berdasarkan uji statistik chi square diperoleh nilai $p=0,253$ jika dibandingkan dengan nilai $\alpha=0,05$, maka $p>\alpha$. Hal tersebut meunjukkan bahwa tidak terdapat hubungan Lingkar Lengan Atas (LILA) dengan kejadian preeklampsia pada ibu hamil di RSUD Dokter Soedarso Pontianak.

Hasil penelitian ini tidak sejalan disampaikan Nur Anas (2013) yang menyatakan ada hubungan signifikan Lingkar Lengan Atas (LILA) dengan preeklampsia pada ibu hamil di RS. PKU Muhammadiyah Surakarta. Dari analisis statistik diperoleh bahwa kadar lemak yang dapat diukur dengan LILA bukan merupakan faktor risiko utama dalam kejadian preeklampsia. Dari Uji Chi-Square diperoleh nilai $p$ sebesar 0,000 .

Pengukuran Lingkar Lengan Atas (LILA) adalah suatu cara untuk mengetahui risiko kekurangan energy protein (KEP) wanita usia subur (WUS). Pengukuran LILA tidak dapat digunakan untuk memantau perubahan status gizi dalam jangka pendek. Pengukuran LILA digunakan karena pengukurannya sangat mudah dan dapat dilakukan oleh siapa saja (Supariasa, 2001). Standar LILA yang dipakai di Indonesia yaitu bila LILA $<23,5 \mathrm{~cm}$ berarti ibu dengan status gizi buruk, sedangkan LILA >23,5 cm adalah ibu yang memiliki status gizi baik dan buruk karena obesitas (Arisman, 2003).

Pada penelitian ini LILA yang diambil yaitu LILA pada kunjungan awal pemeriksaan kehamilan yaitu pada trimester 1 , sedangkan tidak dilakukan pengukuran ulang LILA pada akhir kehamilan (trimester 3). Hal ini dapat menjadi alternatif dalam penelitian lain berikutnya bahwa pengukuran LILA ulang pada trimester 3 dapat dilakukan agar dapat dibandingkan LILA pada trimester 1 dengan trimester 3 apakah mengalami perubahan. Penanggulangan ibu hamil dengan LILA kurang dilaksanakan melalui intervensi gizi secara spesifik terutama pada kunjungan pemeriksaan kehamilan rutin dan melaksanakan rujukan jika diperlukan.

\section{KESIMPULAN}

1. Terdapat hubungan antara status gravida dengan kejadian preeklampsia di RSUD Dokter Soedarso Pontianak

2. Terdapat hubungan antara pertambahan berat badan dengan kejadian preeklampsia di RSUD Dokter Soedarso Pontianak

3. Tidak terdapat hubungan antara Lingkar Lengan Atas (LILA) dengan kejadian preeklampsia di RSUD Dokter Soedarso Pontianak

\section{SARAN}

\section{Responden (Ibu Hamil)}

1. Diharapkan untuk lebih rutin untuk memeriksakan kehamilannya dari trimester 1, trimester 2 dan trimester 3

2. Diharapkan pada Wanita Usia Subur (WUS) terutama wanita yang akan segera hamil dapat lebih memperhatikan status gizinya dengan mengkonsumsi makanan bergizi yang sesuai dengan kebutuhan

3. Diharapkan ibu hamil dapat lebih merencanakan kehamilannya dengan program KB (Keluarga Berencana) agar tidak banyak ibu hamil dengan usia risiko tinggi $>35$ tahun dan dapat mengatur jarak kehamilan ini dengan kehamilan sebelumnya

\section{Rumah Sakit Dokter Soedarso Pontianak Rumah Sakit dapat mencegah terjadinya preeklampsia dalam kehamilan}


dengan lebih menekankan kunjungan pada pemeriksaaan kehamilan agar dapat terdeteksi lebih awal tanda-tanda dan bahaya dalam kehamilan.

\section{Peneliti Lainnya}

Bagi peneliti lain yang akan melakukan penelitian tentang preeklampsia dapat menggunakan variabel lain yang lebih bervariasi seperti yang ditemukan dari penelitian ini. Yaitu usia ibu hamil, asupan makanan pada ibu hamil, Indeks Masa Tubuh (IMT) sebelum hamil, pengukuran Lingkar Lengan Atas (LILA) ulang pada trimester 3 , riwayat penyakit, dan faktor keturunan kaitannya dengan preeklampsia.

\section{UCAPAN TERIMA KASIH}

Penulis mengucapkan terima kasih yang sebesar-besarnya kepada :

1. Dekan Universitas Muhammadiyah Pontianak atas ijinnya dalam melaksanakan tugas penelitian

2. Kepala Bidang Pengembangan RSUD Dokter Soedarso Pontianak yang telah memberikan ijin untuk melakukan penelitian

3. Kepala Ruangan Maternal RSUD Dokter Soedarso Pontianak

4. Tim Bidan Ruangan Maternal RSUD Dokter Soedarso Pontianak

5. Dan seluruh pihak yang turut membantu dalam pelaksanaan penelitian ini yang tak dapat disebutkan satu persatu saya ucapkan terima kasih banyak

\section{DAFTAR PUSTAKA}

Ambarwati, ER dan Rismintari. 2009. Asuhan Kebidanan Komunitas. Mulia Medika Yogyakarta

Anas, Nur. 2013. Hubungan Lingkar Lengan Atas (LILA) Pada Ibu Hamil Dengan Angka Kejadian Preeklampsia di Rumah Sakit PKU Muhammadiyah Surakarta. Skipsi. Surakarta : Program Pasca Sarjana Universitas Muhammadiyah Surakarta, [disitasi pada Desember 2018]. Diakses dari URL : https://core.ac.uk/download/ pdf/148595680.pdf

Arisman, MB. 2003. Gizi Dalam Daur Kehidupan. Jakarta : Penerbit Buku Kedokteran EGC
Artikasari, Kurniawati. 2009. Hubungan Antara Primigravida Dengan Angka Kejadian Preekampsia/Eklampsia di RSUD DR. Moewardi Surakarta. Skripsi. Surakarta : Fakultas Kedokteran Universitas Muhammadiyah Surakarta, [disitasi pada Januari 2019].

Dinas Kesehatan Provinsi Kalimantan Barat, 2016. Profil Dinas Kesehatan Provinsi Kalimantan Barat

Eiland E, Nzerue C, Faulkner M. Review article : preeklampsia 2012. Journal of Pregnancy. 2012; Volume 2012 (586578):1-7.

Firman, F. 2012. Obstetri Patologi Ilmu Kesehatan Reproduksi. Bandung : EGC

Gafur Z, Abdul. 2012. Hubungan Antara Primigravida Dengan Preeklampsia di beberapa Rumah Sakit Provinsi Sulawesi Selatan. [online], vol. 9, no. 3, pp: 142-150, [disitasi pada Maret 2018]. Diakses dari URL : http://jurnal.med.unismuh.ac.id/

Kementrian Kesehatan RI. 2014. Profil Data Kesehatan Dasar Indonesia 2011. Jakarta : Kemenkes RI

Prawirohardjo, Sarwono. 2010. IImu Kebidanan. Jakarta : Yayasan Bina Pustaka Sarwono Prawirohardjo

Serudji, Joserizal. 2013. Hubungan Status Gravida dan Usia lbu terhadap Kejadian Preeklampsia di RSUP Dr. M. Djamil Padang. Jurnal Vol : 4 No :1. Padang : Fakultas Kedokteran Universitas Andalas Padang, [disitasi pada Desember 2018].

Simkin, Penny, Janet Whalley, Ann Keppler. 2010. Panduan Lengkap Kehamilan, Melahirkan, \& Bayi (Edisi Revisi). Jakarta: Arcan

Situmorang $H$ Tigor, Damantalm $Y$, Januarista A, Sukri. 2016. Faktorfaktor Yang Berhubungan Dengan Kejadian Preeklampsia Pada lbu Hamil di Poli KIA RSU Anutapura Palu. [online], vol. 2, no. 1, pp 1 -75, [disitasi pada Januari 2018]. Diakses dari URL: http:/eprints. ums.ac.id/51314/14/NASKAH\%20P UBLIKASI.pdf

Trijatmo, Rachimhadhi. 2007. Preeklampsia dan Eklampsia. Jakarta : Yayasan Bina Pustaka Sarwono Prawiroharjo 
Wantonoro. 2015. Hubungan Paritas Dengan Kejadian Preeklampsia Pada lbu Hamil di RSUD Wonosari. Tesis. Yogyakarta : STIKES Aisyiyah Yogyakarta, [disitasi pada Desember 2018].

WHO. 2014. Safe Motherhood Modul Eklampsi Materi Pendidikan Kebidanan. Jakarta : EGC 


\section{LAMPIRAN}

Tabel 1. Distribusi Frekuensi Responden berdasarkan karakteristik umur, pendidikan terakhir, pekerjaan dan tinggi badan di RSUD Dokter Soedarso Pontianak

\begin{tabular}{ccc}
\hline $\begin{array}{c}\text { Karakteristik Umur } \\
\text { Responden }\end{array}$ & $\mathrm{N}$ & $\begin{array}{c}\text { Persentase } \\
(\%)\end{array}$ \\
\hline$<\mathbf{2 0}$ tahun & 4 & 7,8 \\
$\mathbf{2 1 - 3 5}$ tahun & 23 & 45,1 \\
$\mathbf{3 5}$ tahun & 24 & 47,1 \\
Jumlah & $\mathbf{5 1}$ & $\mathbf{1 0 0}$ \\
\hline & & \\
\hline Karakteristik & $\mathrm{N}$ & Persentase \\
Pendidikan Terakhir & & $(\%)$ \\
Responden & & \\
\hline Tidak Sekolah & 3 & 5,9 \\
Tamat SD & 11 & 21,6 \\
Tamat SMP & 11 & 21,6 \\
Tamat SMA & 24 & 47,0 \\
Tamat Universitas & 2 & 3,9 \\
Jumlah & $\mathbf{5 1}$ & $\mathbf{1 0 0}$ \\
\hline
\end{tabular}

\begin{tabular}{ccc}
\hline $\begin{array}{c}\text { Karakteristik Pekerjaan } \\
\text { Responden }\end{array}$ & N & $\begin{array}{c}\text { Persentase } \\
(\%)\end{array}$ \\
\hline Tidak Bekerja (IRT) & 37 & 72,6 \\
Pegawai Negri & 1 & 1,9 \\
Petani & 4 & 7,9 \\
Swasta & 9 & 17,6 \\
Jumlah & $\mathbf{5 1}$ & $\mathbf{1 0 0}$ \\
\hline
\end{tabular}

\begin{tabular}{ccc}
\hline $\begin{array}{c}\text { Karakteristik Tinggi } \\
\text { Badan Responden }\end{array}$ & N & $\begin{array}{c}\text { Persentase } \\
(\%)\end{array}$ \\
\hline TB $<\mathbf{1 4 5} \mathbf{~ c m}$ & 5 & 9,8 \\
TB $>\mathbf{1 4 5} \mathbf{~ c m}$ & 46 & 90,2 \\
Jumlah & $\mathbf{5 1}$ & $\mathbf{1 0 0}$ \\
\hline
\end{tabular}

Tabel 2. Distribusi Frekuensi Responden berdasarkan status gravida, pertambahan berat badan, ukuran Lingkar Lengan Atas (LILA) di RSUD Dokter Soedarso Pontianak

\begin{tabular}{ccc}
\hline Status Gravida & N & $\begin{array}{c}\text { Persentase } \\
(\%)\end{array}$ \\
\hline Primigravida & 16 & 31,4 \\
Multigravida & 35 & 68,6 \\
Jumlah & $\mathbf{5 1}$ & $\mathbf{1 0 0}$ \\
\hline
\end{tabular}




\begin{tabular}{ccc}
\hline $\begin{array}{c}\text { Pertambahan Berat } \\
\text { Badan }\end{array}$ & N & $\begin{array}{c}\text { Persentase } \\
(\%)\end{array}$ \\
\hline Normal & 25 & 49,0 \\
Berlebih & 26 & 51,0 \\
Jumlah & $\mathbf{5 1}$ & $\mathbf{1 0 0}$ \\
\hline & & \\
\hline Lingkar Lengan Atas & $\mathrm{N}$ & $\begin{array}{c}\text { Persentase } \\
(\%)\end{array}$ \\
\hline LILA) & & 13,7 \\
Risiko KEK & 7 & 86,3 \\
Tidak Risiko KEK & 44 & $\mathbf{1 0 0}$ \\
Jumlah & $\mathbf{5 1}$ & \\
\hline
\end{tabular}

Tabel 3. Hasil Analisis Bivariat status gravida dengan kejadian preeklampsia pada ibu hamil di RSUD Dokter Soedarso Pontianak

\begin{tabular}{|c|c|c|c|c|c|c|c|c|}
\hline \multirow[t]{3}{*}{ Status Gravida } & \multicolumn{4}{|c|}{ Kejadian Preeklampsia } & \multirow{2}{*}{\multicolumn{2}{|c|}{ Total }} & \multirow{2}{*}{$\begin{array}{c}\text { PR (CI } \\
95 \%\end{array}$} & \multirow{2}{*}{$\begin{array}{c}\mathrm{p} \\
\text { value }\end{array}$} \\
\hline & \multicolumn{2}{|c|}{$\begin{array}{c}\text { Preeklamp } \\
\text { sia Berat }\end{array}$} & \multicolumn{2}{|c|}{$\begin{array}{l}\text { Preeklamp } \\
\text { sia Ringan }\end{array}$} & & & & \\
\hline & $\mathrm{N}$ & $\%$ & $\mathrm{~N}$ & $\%$ & $\mathrm{~N}$ & $\%$ & 3,543 & 0,000 \\
\hline Multigravida & 31 & 88,6 & 4 & 25 & 35 & 68,6 & $(1,504-$ & \\
\hline Primigravida & 4 & 11,4 & 12 & 75 & 16 & 31,4 & $8,347)$ & \\
\hline
\end{tabular}

Tabel 4. Hasil Analisis Bivariat pertambahan berat badan dengan kejadian preeklampsia pada ibu hamil di RSUD Dokter Soedarso Pontianak

\begin{tabular}{|c|c|c|c|c|c|c|c|c|}
\hline \multirow{3}{*}{$\begin{array}{l}\text { Pertambahan } \\
\text { Berat Badan }\end{array}$} & \multicolumn{4}{|c|}{ Kejadian Preeklampsia } & \multicolumn{2}{|c|}{ Total } & \multirow{2}{*}{$\begin{array}{c}\text { PR (CI } \\
95 \%\end{array}$} & \multirow{2}{*}{$\begin{array}{c}\mathrm{p} \\
\text { value }\end{array}$} \\
\hline & \multicolumn{2}{|c|}{$\begin{array}{c}\text { Preeklamp } \\
\text { sia Berat }\end{array}$} & \multicolumn{2}{|c|}{$\begin{array}{l}\text { Preeklamp } \\
\text { sia Ringan }\end{array}$} & & & & \\
\hline & $\mathrm{N}$ & $\%$ & $\mathrm{~N}$ & $\%$ & $\mathrm{~N}$ & $\%$ & 1,627 & 0,027 \\
\hline Berlebih & 22 & 62,9 & 4 & 25 & 26 & 51 & $(1,079-$ & \\
\hline Normal & 13 & 37,1 & 12 & 75 & 25 & 49 & $2,454)$ & \\
\hline
\end{tabular}

Tabel 5. Hasil Analisis Bivariat Lingkar Lengan Atas (LILA) dengan kejadian preeklampsia pada ibu hamil di RSUD Dokter Soedarso Pontianak

\begin{tabular}{|c|c|c|c|c|c|c|c|c|}
\hline \multirow{3}{*}{$\begin{array}{c}\text { Lingkar } \\
\text { Lengan Atas } \\
\text { (LILA) }\end{array}$} & \multicolumn{4}{|c|}{ Kejadian Preeklampsia } & \multirow{2}{*}{\multicolumn{2}{|c|}{ Total }} & \multirow{3}{*}{$\begin{array}{c}\text { PR (CI } \\
95 \%\end{array}$} & \multirow{3}{*}{$\begin{array}{c}\mathrm{p} \\
\text { value }\end{array}$} \\
\hline & \multicolumn{2}{|c|}{$\begin{array}{c}\text { Preeklamp } \\
\text { sia Berat }\end{array}$} & \multicolumn{2}{|c|}{$\begin{array}{l}\text { Preeklamp } \\
\text { sia Ringan }\end{array}$} & & & & \\
\hline & $\mathrm{N}$ & $\%$ & $\mathrm{~N}$ & $\%$ & $\mathrm{~N}$ & $\%$ & & \\
\hline Risiko KEK & 3 & 8,6 & 4 & 25 & 7 & 13,7 & 0,589 & \\
\hline $\begin{array}{ll}\text { Tidak Risiko } \\
\text { KEK }\end{array}$ & 32 & 91,4 & 12 & 75 & 44 & 86,3 & $\begin{array}{c}(0,246- \\
1,413)\end{array}$ & 153 \\
\hline
\end{tabular}

